$\longrightarrow-r-$

(日本化学会誌, 1983, ( 7), p. 1099 1101)

(C) 1983 The Chemical Society of Japan

\title{
フェノール類のアルコールによる $O$-アルキル化反応
}

(1983 年 1 月 24 日受 理)

古川功* 橋 本 静 信

\section{1 緒言}

フェノール類を原料とするアルキルアリールェーテルの合成 は, アルキル化剂としてハロゲン化アルキルをアルカリ性の条件 下で反応させる Williamson 法が一般によく知られている。こ れは操作が簡単な上に高収率で目的とするエーテルが得られるた めである。アルキル化剤としては, 硫酸ジメチなどの硫酸エス テル1) 5), p-トルェンスルホン酸やナフタレンスルホン酸などの 芳香族スルホン酸エステル6)7), シュウ酸エステル8), カルボン酸 エステル日)などもハロゲン化アルキルと同様に用いられる。また アンモニウム塩 ${ }^{10)}$, オキソニウム塩 ${ }^{11) 12)}$, スルホニウム塩 ${ }^{13) 14}$ な どのオニウム塩も選択的アルキル化剂としてしばしば利用され る。しかしこれらのアルキル化剤はいずれるアルコールから誘導 される化合物で, アルコールを直接アルキル化剂とする方法では ない。

アルコールとフェノール類から直接アルキルアリールェーテル を合成するには芳香族スルホン酸, 硫酸などの酸触媒が一般に用 いられるが，この種の反応ではジアルキルェーテルならびにオレ

同志社大学工学部工業化学教室, 602 京都市上京区鳥丸 今出川

1) K. Wallenfels, G. Bechtler, R. Kuhn, H. Trischmann, H. Egge, Angew. Chem., Int. Ed., 2, 515(1963).

2) W. Baker, R. I. Savage, J. Chem. Soc., 1938, 1602.

3) H. Bredereck, I. Henning, W. Rau, Chem. Ber., 86, 1085(1953).

4) R. N. Icke, C. E. Redemann, B. B. Wisegarver, G. A. Alles, “Organic Syntheses", Coll. Vol. III, p. 564 (1955).

5) F. Mauthner, “Organic Syntheses”, Coll. Vol. I, p. 537(1948).

6) P. Veeravagu, R. T. Arnold, E. W. Eigenmann, J. Am. Chem. Soc., 86, 3072(1964).

7) D. Klamann, H. Bertsch, Chem. Ber., 88, 201(1955).

8) E. E.Smissman, M. D. Corbett, S. E.-Antably, K. C. Kroboth, J. Org. Chem., 37, 3944(1972).

9) T. Kito, N. Yanai, I. Hirao, Bull. Chem. Soc. Jpn., 45, 3490(1972).

10) C. A. Buehler, D. E. Pearson, "Survey of Organic Syntheses", John Wiley and Sons, Inc., New York, N. Y. (1970) p. 296.

11) H. Meerwein, “Organic Syntheses", Coll. Vol. V, p. 1080, 1096(1973).

12) H. O. House, B. M. Trost, J. Org. Chem., 30, 2502 (1965).

13) R. Kuhn, H. Trischmann, Ann., 611, 117(1958).

14) H. Metzger, H. Konig, K. Seelert, Tetrahedron Lett., 1964, 867.
フィンの副生をともない, かつ高温を要するため前述の方法にく らべ利点が少なく特殊な場合以外はあまり用いられない15)。そこ で中性の緩和な条件下でアルコールを直接アルキル化剂とする方 法として, ジシクロヘキシルカルボジイミドと塩化銅 $(I)^{16) ~ 18), ~}$ アゾジカルボン酸エステルとトリフェニルホスフィン19) 21), 人 キサメチル亜リン酸トリアミドからのホスホニウム塩 ${ }^{22)}$ を脱水剂 として用い好結果を得ている。

一方, 著者らはさきに脱水剂として入手容易なトリフェニルホ スフィンー四塩化炭素系試剤を用いると, 遊離のカルボン酸が直 接フェノール類の ーーアシル化剤となることを見いだ，種々の カルボン酸フェニルエステルを高収率で得た ${ }^{23)}$ 。こで本報では 上記のエステル化反応につづき, アルコールによるフェノールの Oーアルキル化反応について検討したところ, ジアルキルェーテ ルを副生することなく予期したアルキルアリールエーテルが高収 率で得られることを見いたしたのでこれらの結果について報告す る。

\section{2 実験}

\section{1 反応試刜}

トリフェニルホスフィン, 四塩化炭素, アルコール類, フェノ ール類、ベンゼンなどは, いずれる市販特級または一級品を蒸留 または再結晶し GLC で純品であることを確認して使用した。ま

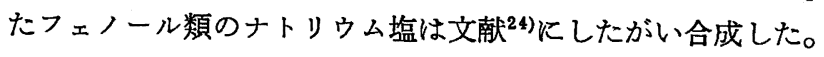

\section{2 アルキルアリールエーテル類の合成}

2.2.1 ナトリウムフェノラート類からの合成：フェノラート 類 $100 \mathrm{mmol}$ とトリフェニルホスフィン $110 \mathrm{mmol}$ をベンゼン $80 \mathrm{ml}$ に溶解, 常圧で含まれている微量の水分をベンゼンとの共 沸混合物として除去し, 残留物にアルコール $35 \mathrm{ml}$, 四塩化炭素

15) K. B.Wiberg, K. A. Saegebarth, J. Org. Chem., 25, 832(1960).

16) E. Vowinkel, Chem. Ber., 99, 42, 1479(1966).

17) H. G. Khorana, Chem. Rev., 53, 145(1953).

18) D. M. Brown, Adv. Org. Chem., 3, 115(1963).

19) S. Bittner, Y.Assaf, Chem. Ind. (London), 1975, 281.

20) M. S. Manhas, W. H. Hoffman, B. Lal, A. K. Bose, J. Chem. Soc., Perkin Trans. 1, 1975, 461.

21) O. Mitsunobu, J. Kimura, K. Iizumi, N. Yanagida, Bull. Chem. Soc. Jpn., 49, 510(1976).

22) I. M. Downie, H. Heaney, G. Kemp, Angew. Chem., Int. Ed., 14, 370(1975).

23) S. Hashimoto, I. Furukawa, Bull. Chem. Soc. Jpn., 54, 2227(1981).

24) N. Kornblum, A. P. Lurie, J. Am. Chem. Soc., 81, 2705(1959). 
Table 1 Synthesis of alkyl phenyl ethers

\begin{tabular}{|c|c|c|c|}
\hline $\begin{array}{c}\mathrm{C}_{6} \mathrm{H}_{5}-\mathrm{O}-\mathrm{R} \\
\mathrm{R}:\end{array}$ & $\begin{array}{l}\text { Yield } \\
(\%)\end{array}$ & $\begin{array}{c}\mathrm{bp}^{a)} \\
\left({ }^{\circ} \mathrm{C} / \mathrm{mmHg}\right)\end{array}$ & $\begin{array}{c}\mathrm{bp}(\text { Lit. }) \\
\left({ }^{\circ} \mathrm{C} / \mathrm{mmHg}\right)\end{array}$ \\
\hline $\mathrm{CH}_{3}$ & 99 & $155 \sim 156$ & $153 \sim 154 / 748^{25)}$ \\
\hline $\mathrm{C}_{2} \mathrm{H}_{5}$ & 90 & $73 \sim 73 / 25$ & $170^{26)}$ \\
\hline$n-\mathrm{C}_{3} \mathrm{H}_{7}$ & 87 & $94 / 25$ & $189^{27)}$ \\
\hline$i-\mathrm{C}_{3} \mathrm{H}_{7}$ & 75 & $63 \sim 65 / 10$ & $177^{27)}$ \\
\hline$n-\mathrm{C}_{4} \mathrm{H}_{9}$ & 81 & $102 / 25$ & $210^{26)}$ \\
\hline$t-\mathrm{C}_{4} \mathrm{H}_{9}$ & 16 & $73 / 22$ & $62 / 10^{27)}$ \\
\hline $\mathrm{CH}_{2}=\mathrm{CHCH}_{2}$ & 88 & $90 / 30$ & $112 \sim 113 / 34^{28)}$ \\
\hline $\mathrm{ClCH}_{2} \mathrm{CH}_{2}$ & 47 & $115 \sim 117 / 30$ & $97 \sim 99 / 10^{7)}$ \\
\hline $\left.\mathrm{CH}_{3} \mathrm{OCH}_{2} \mathrm{CH}_{2}{ }^{b}\right)$ & $66^{c)}$ & Liquid & \\
\hline $\mathrm{C}_{6} \mathrm{H}_{5} \mathrm{CH}_{2}$ & 82 & $\left.34 \sim 35^{d}\right)$ & 38. $4^{(d) 29)}$ \\
\hline
\end{tabular}

a) Uncorrected.

b) $\operatorname{IR}\left(\mathrm{cm}^{-1}\right): 1255\left(\nu_{\mathrm{C}_{6} \mathrm{H}_{5}-\mathrm{O}-\mathrm{R}}\right)$.

${ }^{1} \mathrm{H}-\mathrm{NMR}(\delta, \mathrm{ppm}): 3.30\left(\mathrm{~s}, 3 \mathrm{H}, \mathrm{CH}_{3} \mathrm{O}\right), 3.56(\mathrm{t}$, $2 \mathrm{H}, \mathrm{CH}_{3} \mathrm{OCH}_{2} \mathrm{CH}_{2} \mathrm{O}$ ), 3. $97\left(\mathrm{t}, 2 \mathrm{H}, \mathrm{CH}_{3} \mathrm{OCH}_{2} \mathrm{CH}_{2}\right.$ O), 6. $70 \sim 7.35(\mathrm{~m}, 5 \mathrm{H}$, arom. ). $\mathrm{MS}(m / e): \mathrm{M}^{+}=152$.

c) Isolated by column chromatography(Support; Silica gel, Eluent; Benzene).

d) Melting point.

$15 \mathrm{ml}$ を加え， 3 時間加熱還流した。のち副生した塩化ナトリウ ムを汇別, 汇夜中のベンゼン, アルコールならびに四塩化炭素を 留去後, 残留物にヘキサンを加え不溶のトリフェニルホスフィン オキシドを汇別した。洰液は水酸化ナトリウム水溶液, ついで水 で洗浄後無水硫酸マグネシウムで乾燥，のち蒸留またはカラムク ロマトグラフィー（充填剤；シリカゲル，展開溶媒；ベンゼン） で精製単離した。また生成エーテルは MS (日立製作所製, RM50 GC 型), IR (島津製作所製, IR-27 C 型)，NMR (日立製作 所製，R-24 型)によって同定した。

2.2.2 フェノール類とピペラジンからの合成：ナトリウムフ ェノラートのかわりにフェノールとピペラジンを用い前記同様に 反応処理した。

\section{3 結 果と考察}

ナトリウムタェノラートを用い種々のアルコールと反応した結 果を表 1 に示した。一部の例外を除きいずれる高収率で予期した アルキルフェニルェーテルを与えた。アルュールとして第一級ア ルコールを用いると $80 \%$ 以上の収率であるが，電子求引基をも つ2ーメトキシーおよび 2-クロロエタノールで楉平収率が低下 した。また 2-プロパノールでは 75\%，2-メチル-2-プロパノー ルでは $16 \%$ となり, 分岐度が大きいアルコールほどェーテル類 の収率は低下した。

一方, 種々の置換基をもつフェノール類とェタノールからのェ 一テル類の収率を表 2 に示した。一部の例外を除きいずれる高収 率で予期したェーテル類を与えた。フェノール類中の置換基の電

25) G. S. Hiers, F. D. Hager, "Organic Syntheseș", Coll. Vol. I, p. 58(1948).

26) R. R. Dreisbach, R. A. Martin, Ind. Eng. Chem., 41, 2875(1949).

27) W. T. Olson et al., J. Am. Chem. Soc., 69, 2451(1947).

28) C. D. Hurd, L. Schmerling, ibid., 59, 107(1937).

29) E. M. Pitsh, H. D. Hinrichs, E. Kasparek, Z. Elektrochem., 49, 368(1943).
Table 2 Synthesis of aryl ethyl ethers

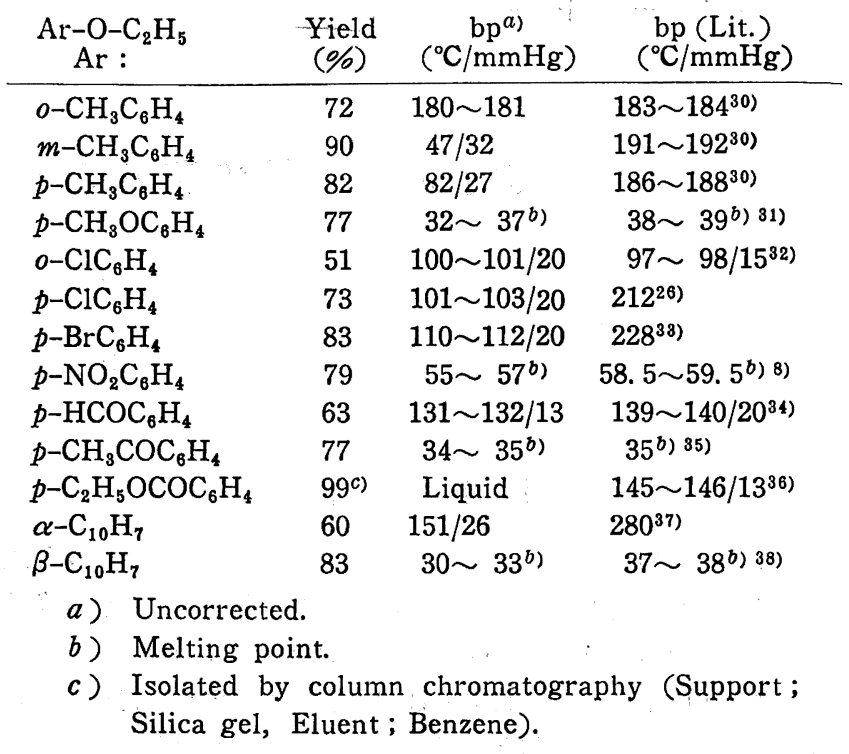

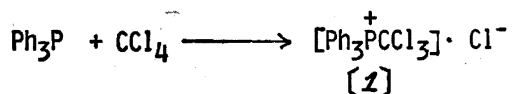

[1] + ArONa $\left.\stackrel{-\mathrm{NaCl}}{\longrightarrow} \underset{\left[\mathrm{Ph}_{3} \stackrel{+}{\mathrm{PCCl}}\right.}{\stackrel{+}{[}]}\right] \cdot \mathrm{ArO}^{-}$

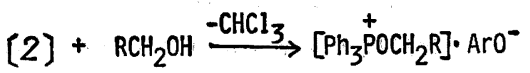

(3)

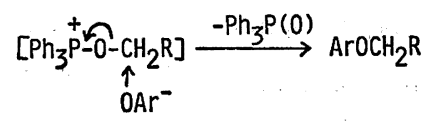

気的性質とェーテルの収率との間には相関関係は認められなかっ た。しかし ーークレゾールのよらに立体障害の認められるものは 若干収率が低下した。また $p$ 一ヒドロキシ安息香酸エチルのよう なェステル結合をもつフェノール類は, 本反応によってもェステ ル結合は開裂を受けず高収率でエーテルを与えた。

本反応はトリフェニルホスフィンと四塩化炭素から生じた(ト リクロロメチル)トリフェニルホスホニウム塩 [1]がナトリウ ムフェノラートによってアニオン交換したホスホニウム塩 [2] となり,このものにアルコールが求核攻撃することによってアル コキシホスホニウム塩 [3]を生成, ホスフィンオキシドが脱離 すると同時に炭素原子へフェノラートアニオンが攻撃する機構で

30） N. Z. Patel, K. S. Nargund, J. Univ. Bombay, Sect. $A$, 15, Pt. 3, 31(1946); Chem. Abstr., 41, 6200 (1947).

31) D. Vorländer, K. Ost, Chem. Ber., 71 B, 1688(1939).

32) W. F. Anzilott, B. C. Curran, J. Am. Chem. Soc., 65, 607(1943).

33) D. M. Birosel, ibid., 53, 1408(1931).

34) M.Sommelet, I. Marszak, Compt. Rend., 198, 2256 (1934).

35) G. M. Kosolapoff, J. Am. Chem. Soc., 69, 1651(1947).

36) J. Houben, W. Fischer, Chem. Ber., 64, 240(1931).

37) V. H. Dermer, O.C. Demer, J.Org. Chem., 3, 289 (1938).

38) D. M. Musser, H. Adkins, J. Am. Chem. Soc., 60, 664 (1938). 
エーテルが生成する。このさい電子求引基をもつアルコールから のホスホニウム塩 [3]はホスフィンオキシドの脱離が起こり難 く, 一方, 分肢アルュールからの[3]はフェノラートアニオン による求核反応よりも脱プロトン化反応が優先して起こるため に，いずれの場合もエーテルの収率が低下したものと考えられ る。

一方, フェノラートのかわりにフェノールと塩基としてピペラ
ジンを用いた反応では，相当するェーテルは生成せず塩化エチル のみが生成した。また ともに $12 \%$ の収率で相当するェーテルが得られた。ピペラシン の量は収率にほとんど影響を与えなかった。これは［1]に対す る求核攻撃がフェノールよりもアルコールが優先し，その結果， 八ロゲン化アルキルが生成するためと考えられる。

(1981 年 10 月, 日本化学会第 44 秋季年会発表)

\section{O-Alkylation of Phenols with Alcohols \\ Isao Furukawa* and Shizunobu Hashimoto \\ Department of Applied Chemistry, Doshisha University; Karasuma- imadegawa, Kamigyo-ku, Kyoto-shi 602 Japan}

Alkyl aryl ethers have obtained in a high yield from sodium phenolates with alcohols as an alkylating agent in the presence of triphenylphosphine and carbon tetrachloride under mild conditions. The yields of ethers were hardly affected by the polarity of the substituent on phenols, but it was decreased remarkably by the use of tertiary alcohols as an alkylating agent. The use of a mixture of phenol and piperazine instead of sodium phenolate gave mainly alkyl chlorides. 